\title{
Is The Alchemist soos goud bewaar?
}

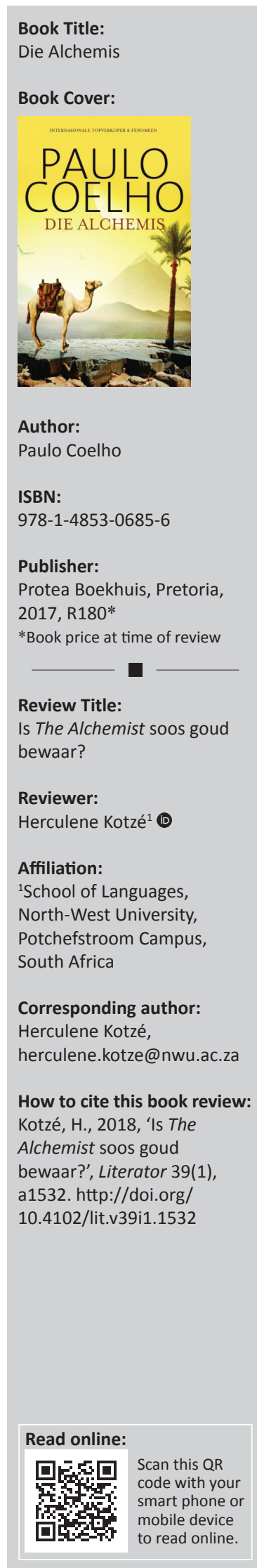

Asof die eerste verskyning van Paulo Coelho se O Alquimista in Portugees (uitgegee deur Editora Rocco, 1988) nie reeds merkwaardig genoeg was nie, volg daar meer as 70 vertalings daarvan. Die opgang van hierdie werk is deur die Engelse vertaling (The Alchemist) verder gevoer, en weldra verskyn dit ook in Afrikaans. Hierdie roman geniet steeds wêreldwyd aansien as een van die mees invloedryke filosofies-literêre werke. Dit fokus op simboliserende wyse op elke mens se destiny, ${ }^{1}$ en volg hierin die verhaal van 'n jong skaapwagter se soeke na geluk. Hierdie werk word onder andere deur 'n Jungiaanse beskouing onderlê van 'n kollektiewe onbewuste wat deur alle lewende wesens gedeel word.

Die eerste lees van die Engelse weergawe (vertaal deur Alan R. Clarke en in 1993 deur Harper Collins uitgegee) was vir my persoonlik verrykend en dit is vandag steeds een van my gunstelingboeke. Ek vra myself wel gereeld af hoeveel lesers (van meet af) besef dat die Engelse boek 'n reeds vertaalde weergawe is. Hierdie bewustheid behoort dan ook die leser van die nuwe Afrikaanse vertaling myns insiens sekere vrae te laat vra: Het die vertaler toegang tot die oorspronklike Portugese weergawe gehad? Het die vertaler toegang tot die outeur gehad? Wat was die vertaler se voorskrifte en natuurlik, wie het opdrag gegee dat die vertaling gedoen word?

In die geval van Die Alchemis, vertaal deur Kobus Geldenhuys en in 2017 deur Protea Boekhuis uitgegee, het ek nie antwoorde op die bogenoemde vrae nie. Dieselfde is waar van die eerste Afrikaanse vertaling van The Alchemist, deur Bennie Naudé vertaal en in 2003 deur Aardvark Press uitgegee. Daarom verander my vertrekpunt noodgedwonge van 'n ingeligte gehaltebeoordeling na 'n tekstuele evaluering van die vertalings.

Die vertaling van so 'n teks is en kan nie as 'n eenvoudige taak beskou word nie. 'n Mens sou selfs kon bevraagteken of die essensie van die verhaal werklik in 'n ander taal oorgedra kan word. Om die waarde van 'n literêre vertaling op so 'n manier te bevraagteken, is egter nie die doel van hierdie resensie nie, en dus steun ek op die werk van Pym (2010:7-8) wat argumenteer dat 'n vertaling inderdaad dieselfde waarde as (ten minste gedeeltes) van die bronteks sal bevat - en hierdie benadering word 'natuurlike ekwivalensie' genoem. Vanwersch-Cot (2011:262) ondersteun hierdie beginsel en voer aan dat die literêre vertaler nie woorde vertaal nie, maar betekenis, ritmes, beelde en konnotasies (my vertaling).

My resensie steun op hierdie teoretiese beskouing: die (her)vertaalde boek moet die betekenis, ritmes, beelde en konnotasies van die bronteks op so 'n wyse aanbied dat die leser dit nie as 'n vertaling ervaar nie, maar as 'n primêre ${ }^{2}$ teks. Om hierin te slaag, het ek enkele kernfrases van sowel die Engelse as die twee Afrikaanse tekste onttrek en aan die hand van Vanwersch-Cot se elemente ontleed.

Op die oog af blyk daar min verskille in die twee Afrikaanse vertalings te wees en ek wonder waarom daar 'n tweede Afrikaanse vertalings onderneem is (Tabel 1).

Mettertyd word dit egter duidelik dat die twee vertalings tog heelwat van mekaar verskil (Tabel 2).

In die geïdentifiseerde frases vertaal Naudé 'he muttered' met 'dink hy hardop', terwyl Geldenhuys 'brom' gebruik. Kontekstueel sou 'mompel' in beide gevalle dalk 'n beter keuse gewees het - die situasie gee min aanduiding dat die seun geïrriteerd is deur die skape - wat ' $n$ mens van 'brom' aflei. In teenstelling hiermee weerspieël 'dink hy hardop' 'n afwesigheid van emosie, wat ook nie akkuraat is nie.

1.Die Engelse woord destiny word doelbewus behou eerder as 'lot' of selfs 'bestemming'. Die beginsel word in die Engelse boek gebruik om meer weer te gee as waarvoor die Afrikaanse term - volgens my - ruimte laat.

2.'Primêre' teks verwys hier na Even-Zohar (1987) se teorie dat vertaalde tekste sentrale posisies in ' $n$ sisteem kan inneem en nie as ' $n$ tweederangse teks beskou word nie. 
TABEL 1: Soortgelyke vertaalstrategieë

\begin{tabular}{lcl}
\hline Uitgawe & Bladsynommer & Aanhaling \\
\hline Engels (1993) & 3 & $\begin{array}{l}\text { 'There were no wolves in the region, but once } \\
\text { an animal had strayed during the night, and } \\
\text { the boy had had to spend the entire next day } \\
\text { searching for it.' }\end{array}$ \\
Afrikaans (2003) & 1 & $\begin{array}{l}\text { 'Daar was nie wolwe in die area nie, maar een } \\
\text { van sy skape het eenmaal in die nag } \\
\text { weggeloop en dit het die seun 'n hele dag } \\
\text { geneem om hom te vind.' }\end{array}$ \\
Afrikaans (2017) & 15 & $\begin{array}{l}\text { 'Daar is nie wolwe in die omgewing nie, maar } \\
\text { 'n dier het eenkeer in die nag weggeloop en } \\
\text { die seun moes die hele volgende dag na hom } \\
\text { soek.' }\end{array}$ \\
\hline
\end{tabular}

TABEL 2: Verskillende vertaalstrategieë

\begin{tabular}{|c|c|c|}
\hline Uitgawe & Bladsynommer & Aanhaling \\
\hline Engels (1993) & 4 & $\begin{array}{l}\text { '"They are so used to me that they know my } \\
\text { schedule", he muttered. Thinking about that } \\
\text { for a moment, he realized that it could be the } \\
\text { other way around: that it was he who had } \\
\text { become accustomed to their schedule.' } \\
\text { (outeur se beklemtoning) }\end{array}$ \\
\hline Afrikaans (2003) & $1-2$ & $\begin{array}{l}\text { "Hulle is al so gewoond aan my dat hulle my } \\
\text { roetine ken", dink hy hardop. En dan besef hy } \\
\text { skielik dat dit net sowel hy kan wees wat } \\
\text { gewoond geraak het aan húlle roetine. (outeur } \\
\text { se beklemtoning) }\end{array}$ \\
\hline Afrikaans (2017) & $15-16$ & $\begin{array}{l}\text { '"Hulle is al so gewoond aan my dat hulle my } \\
\text { ritme ken", brom hy. Hy dink 'n oomblik } \\
\text { daaroor en besef dit kan ook andersom wees: } \\
\text { dat hy die een is wat húlle manier van doen } \\
\text { gewoond geraak het.' (outeur se } \\
\text { beklemtoning) }\end{array}$ \\
\hline
\end{tabular}

TABEL 3: Verskillende vertaalstrategieë II

\begin{tabular}{|c|c|c|}
\hline Uitgawe & Bladsynommer & Aanhaling \\
\hline Engels (1993) & 5 & $\begin{array}{l}\text { '"I need to sell some wool", the boy told the } \\
\text { merchant.' (outeur se beklemtoning) }\end{array}$ \\
\hline Afrikaans (2003) & 2 & $\begin{array}{l}\text { "Ek het wol om te verkoop", het die seun aan } \\
\text { die handelaar gesê.' (outeur se beklemtoning) }\end{array}$ \\
\hline Afrikaans (2017) & 17 & $\begin{array}{l}\text { '“Ek moet wol verkoop”, het die seun vir die } \\
\text { handelaar gesê.' (outeur se beklemtoning) }\end{array}$ \\
\hline
\end{tabular}

Hierdie tipe verskille is deurgaans in die vertalings te vind (Tabel 3).

Waar Naudé telkens verkies om op 'n neutraler wyse te vertaal, poog Geldenhuys om emosie weer te gee, maar op 'n onidiomatiese wyse. 'n Meer akkurate vertaling kon wees: 'Ek het wol wat ek moet verkoop', wat beide die oorspronklike konteks weerspieël en meer idiomatiese taalgebruik is.

Nog 'n voorbeeld hiervan kan in die volgende uittreksels gesien word (Tabel 4).

Die insluiting van 'op'n stadium' in Geldenhuys se vertaling is dalk meer getrou aan die Engelse bronteks se 'at one point', maar is onnodig gegewe die konteks en word suksesvol deur Naudé uitgelaat sonder dat enige betekenis verlore gaan.

As dit om die inhoud en akkuraatheid gaan, is dit' $n$ jammerte dat Geldenhuys 'n belangrike frase verkeerd vertaal het (Tabel 5).
TABEL 4: Verskillende vertaalstrategieë III

\begin{tabular}{lcl}
\hline Uitgawe & Bladsynommer & Aanhaling \\
\hline Engels (1993) & 5 & $\begin{array}{l}\text { '“How did you learn to read?", the girl } \\
\text { asked at one point.' }\end{array}$ \\
Afrikaans (2003) & 3 & $\begin{array}{l}\text { '“Hoe het jy leer lees?" wou die meisie } \\
\text { weet.' }\end{array}$ \\
Afrikaans (2017) & 17 & $\begin{array}{l}\text { '“Hoe het jy geleer lees?" vra die meisie op } \\
\text { 'n stadium.' }\end{array}$ \\
\hline
\end{tabular}

TABEL 5: Vertaalfout

\begin{tabular}{lcl}
\hline Uitgawe & Bladsynommer & Aanhaling \\
\hline Engels (1993) & 15 & $\begin{array}{l}\text { 'Then I don't get paid. It wouldn't be the } \\
\text { first time.' (outeur se beklemtoning) }\end{array}$ \\
Afrikaans (2003) & 12 & $\begin{array}{l}\text { 'Dan word ek nie betaal nie. Dit sal nie die } \\
\text { eerste keer wees nie.' (outeur se } \\
\text { beklemtoning) }\end{array}$ \\
Afrikaans (2017) & 27 & $\begin{array}{l}\text { 'Dan word ek nie betaal nie. Dit sal die } \\
\text { eerste keer wees.' (outeur se beklemtoning) }\end{array}$ \\
\hline
\end{tabular}

Vanuit bostaande voorbeelde kan die gevolgtrekking gemaak word dat die twee Afrikaanse vertalings tipies is wanneer dit om geskiktheid teenoor gepastheid gaan, wanneer 'n mens vertaalnorme beskou, en getrouheid teenoor óf die bronteks of kultuur, óf die doelteks of kultuur by die gesprek betrek. Waar Geldenhuys se vertaling as getrou teenoor die bronteks (in hierdie geval die Engels) beskryf kan word, kan Naudé se vertaling as getrou ten opsigte van die doeltaal of -kultuur (Afrikaans) beskryf word. Daar is meriete in beide vertaalbenaderings, maar in die lig van die voorafgenoemde (en die feit dat daar nie antwoorde op die tipiese vrae is as dit om vertaalopdragte en toegang tot die oorspronklike Portugese teks of die outeur gaan nie), verkies ek nie een bo die ander een nie - en ek wonder steeds hoekom die Engelse weergawe twee maal in Afrikaans vertaal is.

Die waarde van die vertaalde weergawes lê in die toeganklikheid. Die oorspronklike Portugees sal waarskynlik deur min Afrikaanssprekendes gelees kan word. Alhoewel hierdie probleem deur die Engelse vertaling opgelos is, is dit verstaanbaar dat die Afrikaanse boek- en leesliefhebbers eerder in hulle eerste taal wil lees vir ontspanning - en dus sal die boek by Afrikaanssprekendes belangstelling wek.

Ter opsomming: Beide Afrikaanse vertalings kan verbeter word. Die Engelse teks word, myns insiens, nie volkome deur een van die twee Afrikaanse vertalings soos goud bewaar nie. Terwyl elkeen meriete het, kon afronding meer aandag geniet het om te verseker dat die betekenis, ritmes, beelde en konnotasies wat in die Engelse weergawe verskyn, behoue gebly het.

\section{Literatuurverwysings}

Even-Zohar, I., 1978, 'The position of translated literature within the literary polysystem', in L. Venuti (ed.). The translation studies reader, 2nd edn., pp. 99204, Routledge, London.

Pym, A., 2010, Exploring translation theories, pp. 7-24, Routledge, London.

Vanwersch-Cot, O., 2011, 'The problem of self-assessment in literary translation', in I. Depraetere (ed.), Perspectives on translation quality, pp. 249-263, De Gruyter, Cumberland. 